

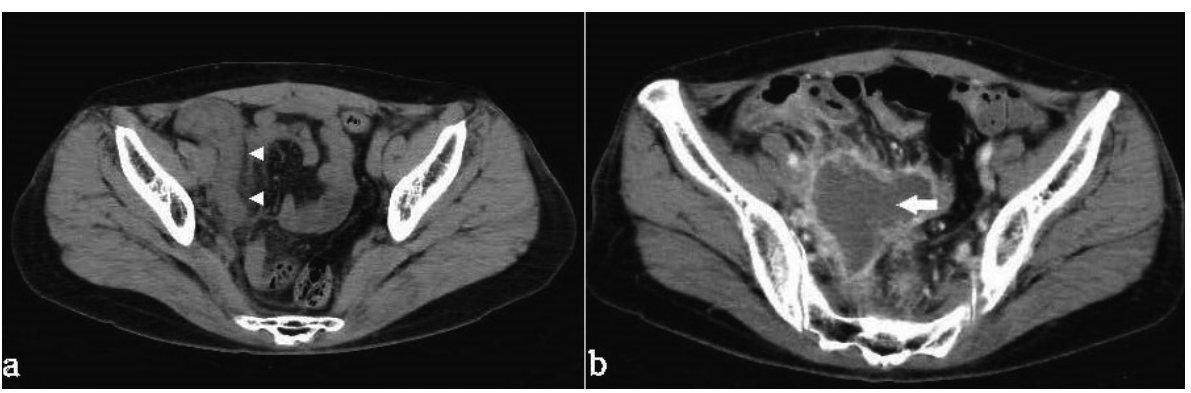

Fig. 1 腹部 CT：a）腫大した虫垂炎を認める (矢頭). b ) 虫垂周囲に膿瘍形成を認める (矢印).

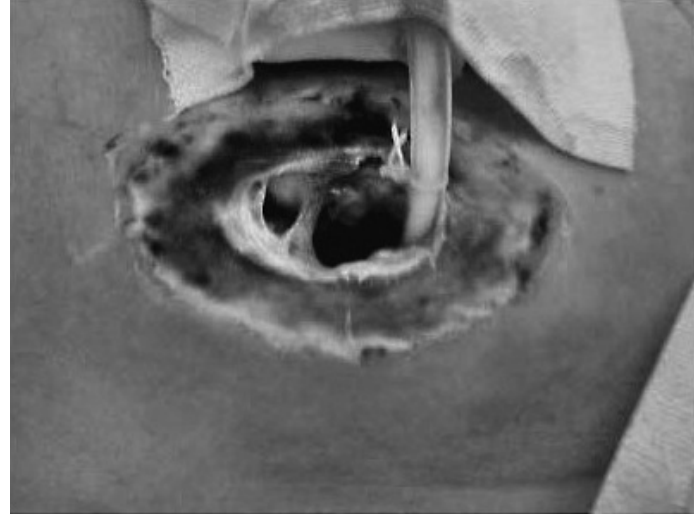

Fig. 2 腹部写真 : 腹壁は全層性に壊死しポケットを形 成.

腸部分切除, 膿瘍ドレナージ術を施行した。

病理組織診断：虫垂自体はほとんど壊死性組織であ り，一部残存した虫垂粘膜にはびらん潰瘍性変化と全 層性に著明な炎症細胞浸潤を認めた。急性壊疽性虫垂 炎の診断であった。

術後経過：術後のドレーンの排液は, 当初は淡々血 性へと改善したが，その後次第に粘調度の高い血性へ と変化した. 粘性が強くドレナージ不良であったため, 適宜ドレーン交換，洗浄を行ったがドレナージ不良は 改善せずCTでも遺残膿瘍を認めた。 $39^{\circ} \mathrm{C}$ 台の発熱が 持続し, ドレーン排液の細菌培養検査では腸内細菌の みの検出であったが, 抗生物質も無効でありドレナー ジ不良が一番の原因と考えられた。 ドレーンの刺入部 は蜂窩織炎から徐々に潰瘍へと悪化し，ついには腹壁 壊死へと進展し大きなポケットを形成した（Fig. 2). 術後20病日のドレーン排液の鏡検にてアメーバ虫体が 確認され（Fig. 3）アメーバ感染症と診断，メトロニ ダゾール投与を開始した。抗アメーバ療法開始 2 日後
にはドレーンの性状が粘血性からカフェオレ様の排液 へと変化し排液量が激減, 炎症反応も速やかに改善傾 向を認め, 抗アメーバ療法が著効していた（Fig. 4). しかし, 術後23病日より急激に浮腫の増悪, 呼吸苦が 出現しCPAP装着するも酸素化が不十分なために人 工呼吸器管理とした。経胸壁心エコー検査にてEF 26 \%と著明な収縮能の低下, 僧帽弁冕脱を伴う severe MRを認め, 循環動態も不安定なことからIABPを装 着しCCU管理となった. 経食道心エコー検査にて明 らかな㽼贅や僧帽弁の腱断裂などは認めず，感染性心 内膜炎は否定的なため敗血症性心筋障害による急性心 不全と診断した。エンドトキシン吸着療法, CHDFと 同時に抗アメーバ療法を継続したが，治療への反応は 非常に良好であり，術後41病日には補助循環装置や人 工呼吸器からも離脱でき $\mathrm{EF} 60 \%, \mathrm{MR}$ も消失し心機 能も改善した。 また，CCU管理中にドレーンより便 汁排出を認め, ドレーン造影にて切離部とは別の部位 の盲腸に瘦孔を認めた。 ドレナージは良好であったた め保存的加療を継続とし, 術後68病日には瘦孔は完全 閉鎖できた。また, 腹壁壊死の部位も抗アメーバ療法 後は肉芽増生良好となり, 術後72病日には完全に創閉 鎖した。腰痛によりリハビリを要したが術後99病日に 自宅退院となった。

\section{考察}

アメーバ感染症は赤痢アメーバ (Entamoeba histolytica）原虫の感染により引き起こされ，腸管アメー バ症（アメーバ性大腸炎）と腸管外アメーバ症（肝膿 瘍など）に分類される．赤痢アメーバに感染したヒト のうち $10 〜 20 \%$ が発症するといわれている．赤痢アメ 一バは感染症法に基づく 5 類全数把握疾患である. 1990年代に年間100〜200例であったのが2000年以降に 急増し，2013年には1,000例を超えるようになった。 


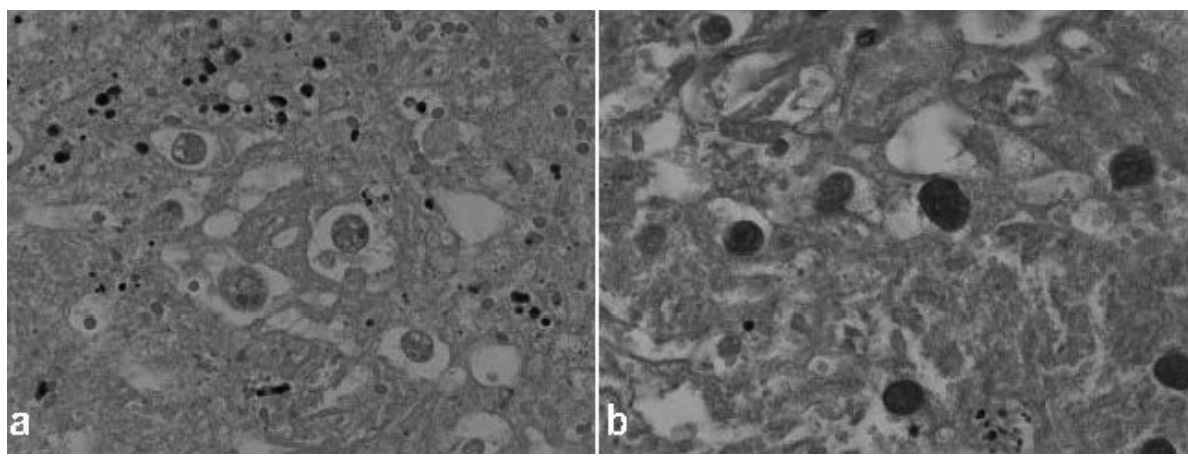

Fig. 3 病理組織像：膿瘍排液中に多数のPAS染色陽性アメーバ栄養体を認める（a：H.E.染色, $\times 400$ ， b : PAS染色, $\times 400)$.

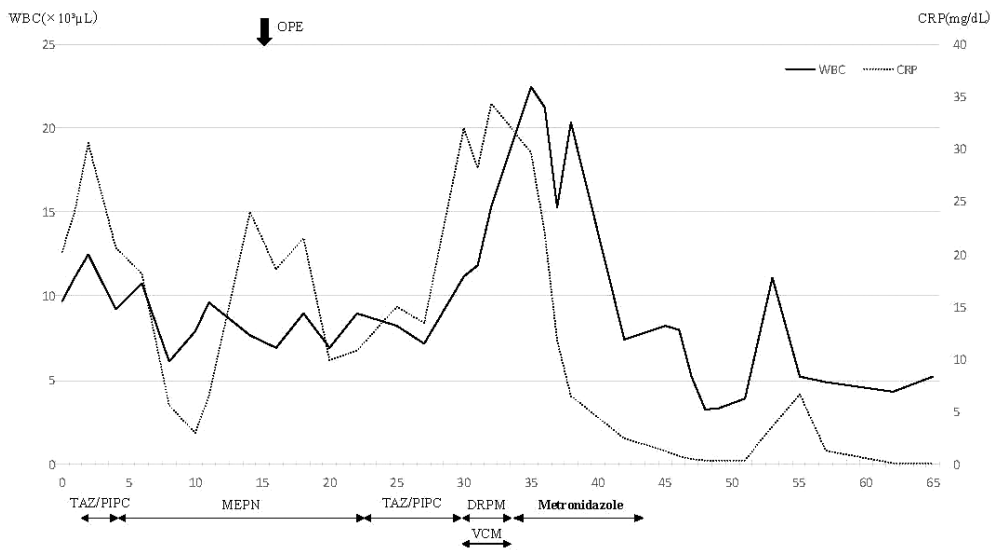

Fig. 4 臨床経過

2018年以降は若干減少し，現在は800例程度で推移し ている1)。以前は発展途上国への渡航者による輸入感 染症として知られていたが, 近年では男性同性愛者や 異性間性的感染の割合が増え, 性感染症（sexually transmitted disease ; STD) の代表的疾患とされてい る。また，性風俗産業従事者を中心に女性においても 増加傾向にある2).

赤痢アメーバにはシスト（囊子）と栄養型が存在す る.ヒトは成熟したシストを経口摂取することにより 感染する. 感染力を持つのは成熟したシストのみであ り, 栄養型や未熟なシストに感染力はない. シストは キチン質で覆われており，湿潤な環境下であれば数週 間生存できる。胃酸にも抵抗性であるため, 感染力を 保持したまま上部消化管を通過できる。体内に侵入し たシストは小腸で脱囊し栄養型となり大腸に移動す る. 多くの栄養型は粘膜に侵入せずにシストを形成す
るため全感染者の約 $90 \%$ は無症候性感染もしくは軽度 の下痢のみとなり, シストが粪便とともに体外に排出 され自然軽快する。しかし，一部の栄養型は腸管粘膜 上皮に侵入し組織を破壊させると有症候性感染とな り，下痢や粘血便を引き起こす3)。粘血便はその外観 から，イチゴジャム状と例えられる，栄養型原虫に感 染力はなく体外に出ると死滅する. 潜伏期は $2 \sim 3$ 週間とされるが, 数力月〜数年間に及ぶこともある ${ }^{4)}$. 自験例では，急性虫垂炎発症の約 3 週間前から $39^{\circ} \mathrm{C}$ の 発熱を認めていたが，下痢や粘血便など消化器症状は 全く認めておらず, 腸管外アメーバ症の所見も認めて いないためアメーバ感染との関連は不明である。

急性虫垂炎は, 緊急手術を要する疾患として最も一 般的な疾患である. 虫垂が粪石や腫瘍, リンパ濾胞形 成, 異物などで閉塞し, 虫垂内圧が上昇して虫垂内で の腸内細菌の異常増殖や虫垂壁の浮腫から発生すると 
Table 1 アメーバ性急性虫垂炎の本邦報告例

\begin{tabular}{|c|c|c|c|c|c|c|c|c|c|c|}
\hline 報告者 & 報告年 & 年齢 & 性別 & 海外渡航歴 & 性的感染 & 併存疾患 & 腹腔内膿瘍 & 肝膿瘍合併 & 術後合併症 & 転帰 \\
\hline 松田8) & 1995 & 35 & M & + & + & HIV & + & - & 回腸穿孔 & 軽快 \\
\hline 三枝9) & 1997 & 38 & M & & + & & & & & 軽快 \\
\hline Gotohda $^{10)}$ & 2000 & 45 & M & - & & & - & - & - & 軽快 \\
\hline 鈴木11) & 2005 & 60 代 & M & & & $\mathrm{LC}$ & + & - & MOF & 死亡 \\
\hline 宮坂 ${ }^{12)}$ & 2005 & 25 & M & + & + & HIV & - & - & - & 軽快 \\
\hline 奥村13) & 2006 & 25 & $\mathrm{~F}$ & + & - & HIV & - & - & & 軽快 \\
\hline 古城 ${ }^{14)}$ & 2011 & 53 & M & + & - & HIV, HCV, DM & + & + & 腹壁壞死，盲腸穿孔，MOF & 死亡 \\
\hline 園生 ${ }^{15)}$ & 2012 & 52 & M & & + & DM & - & + & 腸管壊死, 腹腔内出血, 多臓器膿瘍 & 死亡 \\
\hline 安倍16) & 2013 & 52 & M & + & - & & - & - & - & 軽快 \\
\hline 増田 ${ }^{17)}$ & 2014 & 41 & M & + & & - & - & + & - & 軽快 \\
\hline 中村18) & 2014 & 42 & $\mathrm{~F}$ & - & + & - & - & - & - & 軽快 \\
\hline 森19) & 2015 & 54 & M & - & - & - & - & - & DIC & 死亡 \\
\hline 竹ノ谷 ${ }^{20)}$ & 2015 & 53 & $\mathrm{~F}$ & - & - & - & + & - & 腹壁壊死，結腸穿孔 & 軽快 \\
\hline Ichikawa $^{21)}$ & 2016 & 47 & M & - & & - & - & - & - & 軽快 \\
\hline 出井 22$)$ & 2017 & 46 & M & - & - & $\mathrm{DM}$ & - & - & - & 軽快 \\
\hline 阪本 ${ }^{23)}$ & 2018 & 45 & M & + & - & - & - & + & - & 軽快 \\
\hline 自験例 & 2021 & 48 & $\mathrm{~F}$ & - & + & - & + & - & 腹壁壊死, 回腸盲腸穿孔, 心筋炎 & 軽快 \\
\hline
\end{tabular}

考えられているが, 発症のメカニズムの詳細は不明で ある。しかし，急性虫垂炎の基本病態は感染症であり， 一般的には腸内細菌科 (Escherichia coliやKlebsiella $s p p$. など）や嫌気性菌（Bacteroides spp.），グラム 陽性球菌 (Enterococcus spp. やStreptococcus spp. など）など消化管の正常細菌叢を構成する複数の菌が 関与しているとされる5 . アメーバ由来の急性虫垂炎 は非常にまれであり, 発展途上国などのアメーバ流行 地域では全急性虫垂炎の $0.5 \%$ ～2.3\%と言われてい る ${ }^{6)}$. Otanらは, アメーバ性虫垂炎の自覚症状に特異 的な症状や所見は乏しく，右下腹部痛が $98 \%$, 発熱が $87 \%$ ，下痢が $14 \%$ に見られたと報告している ${ }^{4)}$. 画像 検査にも特異的な所見がないために，術前にアメーバ 性虫垂炎を診断することは困難である。日本のような 流行地域ではない先進国ではさらに困難となる。しか し, Itoらは日本におけるアメーバ性虫垂炎の検討に おいて, 複雑性虫垂炎の割合が高く, アメーバ感染以 外の虫垂炎と比べ死亡率や周術期合併症の頻度が高い と報告している7)。 Otanらは174例の検討にて, 25.4 $\%$ に肝膿瘍 · 腹腔内感染症 ・腸管穿孔 ・ 出血などの何 らかの術後合併症を認め, 死亡率は $3.2 \%$ たったと報 告している ${ }^{4)}$. 診断, 治療の遅れが重篤な合併症や術 死へとつながる可能性がある.

医学中央雑誌にて「虫垂炎」「アメーバ」をキーワ ードに1990年〜2020年で検索した中で，虫垂炎にて発 症し外科手術を行った症例は16例（会議録を除く）が

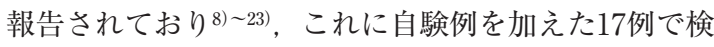
討した（Table 1). 男女比は13：4で男性に多く,
平均年齢は43.8歳であった。このうち海外渡航歴のあ る症例が 7 例，同性間性的接触など性的感染が原因と 考えられる症例が 6 例認めた。併存疾患として HIV 感染が 4 例に認めた。 4 例に死亡症例を認めており， 死亡率としては $23.5 \%$ と非常に高かった，死亡症例 4 例のすべてにおいて生前にアメーバ感染症の診断はつ いていなかった．粘血便などアメーバ赤痢に特徵的な 症状や, 肝膿瘍など腸管外アメーバ症に特徵的な所見 を伴う場合は, アメーバ感染を鑑別に挙げることは比 較的容易であると思われるが，そういった症状を伴わ ない場合は非常に診断が困難である。しかし，特に膿 瘍形成を伴う症例においては，アメーバが腹腔内に散 布されているため適切に診断，治療が行われないと感 染をコントロールすることができず, 敗血症, 多臓器 不全へとつながり生命の危険性を伴うこととなる。ア メーバ性急性虫垂炎17例のうち，摘出した虫垂組織に てアメーバ虫体を確認し確定診断をつけることができ た症例は 8 例 $(47.1 \%)$, 他の検査で診断確定後に再 確認しアメーバ虫体を確認できた症例は 3 例 $(17.6 \%)$ であり，最終的に手術時の検体で診断を確定できた症 例は11例 $(64.5 \%)$ に過ぎなかった. 残りの症例は, 肝膿瘍・腹壁膿瘍からの追加検査での検出や剖検例な どであった．組織検体の状態や標本作成方法（作成部 位や標本数など)，アメーバ虫体の量などで結果が偽 陰性となる可能性が考えられる.

自験例では虫垂切除検体にアメーバ虫体は確認でき なかった，虫垂のほとんどが壊死，融解しており，根 部のほんの一部のみしか残っていなかったために検体 
量が少なかったことが影響したと考えられる。アメー バ感染を疑うことができなかったため，膿瘍ドレナー ジと広域性抗生物質投与を継続したが病状は悪化の一 途をたどった，術後20病日にようやくアメーバ感染を 疑い, ドレナージ排液の鏡検にてアメーバ虫体を確認 でき確定診断をつけることができた．治療が遅れたこ とにより, 腹腔内膿瘍 ·腹壁壊死 ·腸管穿孔 · 感染性 心筋炎といった重篤な合併症を引き起こし, 一時はシ ヨック状態を呈したが手遅れになる前に抗アメーバ療 法を開始できたことで何とか救命することができた. アメーバ感染症の診断後に, 患者背景を再聴取したと ころ性風俗産業従事者であることが判明した。主訴や 症状, 理学的所見だけではなく, 生活歴など患者背景 の詳細な問診も正確な診断や治療にとって非常に重要 だと思われる。穓石などの閉塞機転を伴わない膿瘍形 成性急性虫垂炎や急性虫垂炎の術後経過で合併症を併 発し治療に難渋した場合は, アメーバ感染症も念頭に 置く必要がある。アメーバの鑑別を意識した組織診断 や陰性の場合でも疑わしい場合は血清抗体など測定す ることで早期に診断もしくは除外診断をする必要があ ると思われる。

\section{結語}

今回われわれは，急性虫垂炎の術後に腹壁壊死・腸 管穿孔・感染性心筋炎を合併症するも, 赤痢アメーバ 感染と判明後は抗アメーバ療法が著効し救命しえた症 例を経験したので，文献的考察を加えて報告する。

利益相反：なし

\section{文献}

1）国立感染症研究所 感染症法に基づくアメーバ赤痢 の届け出状況2014年 2019年, (Accessed Jun. 4,2020, at https : //www. niid.go.jp/niid/ja/ entamoebahistolytica-m/entamoeba-histolytica-idwrs/ 9653-amebiasis-200604.html )

2) Ishikane M, Arima Y, Kanayama A, et al : Epidemiology of domestically acquired amebiasis in Japan 2000-2013. Am Trop Med Hyg 2016 ; 94 : $1008-1014$

3）田中美緒, 濱野真二郎：アメーバ赤痢. 医と薬学 $2017 ; 74: 1399-1405$

4) Otan E, Akbulut S, Kayaalp C: Amebic acute appendicitis : systematic review of 174 cases. World J Surg 2013 ; 37 : 2061 - 2073

5) Flum DR, Steinberg SD, Sarkis AY, et al : Ap- pendicitis in patients with acuquired immunodeficiency syndrome. J Am Coll Surg 1997 ; 184 : $481-486$

6) Guzman-Valdivia G : Acute amebic appendicitis. World J Surg 2006 ; 30 : $1038-1042$

7) Ito D, Hata S, Shimizu S, et al : Amebiasis presenting as acute appendicitis : Report of a case and review of Japanese literature. Int J Surg Case Rep 2014 ; 5 : $1054-1057$

8）松田圭二, 齋藤英昭, 金沢孝満他：虫垂炎にて発 症した同性愛者赤痢アメーバ症の 1 例. 臨外 $1995 ; 50: 389-383$

9）三枝弘志, 星野正巳, 山田博基他 : 急性虫垂炎 · 肝膿瘍を合併したアメーバ赤痢の 1 例. 日救急医 会関東誌 $1997 ; 18: 46-47$

10) Gotohda N, Itano S, Okada Y, et al : Acute appendicitis caused by amebiasis. J Gastroenterol $2000 ; 35: 861-863$

11）鈴木康弘, 足立 靖, 安水良知他：生前に診断困 難であった赤痢アメーバ感染症の 2 剖検例. 診断 病理 $2005 ; 22: 25-28$

12）宮坂義浩, 安井大介, 中川真宗他：赤痢アメーバ による急性虫垂炎の 1 例. 消外 $2005 ; 28: 503$ $-506$

13）奥村憲二，李 哲柱，遠藤善裕他：虫垂炎として 発症したアメーバ性大腸炎の 1 例。日消外会誌 $2006 ; 39: 1547-1552$

14）古城 都, 寺坂勇亮, 三宅 亮他：急性虫垂炎か ら発症し, 多発性肝膿瘍, 敗血症にて死亡したア メーバ赤痢合併AIDS患者の 1 例. 日外感染症会 誌 $2011 ； 8 ： 387-391$

15）園生智弘, 水越幸輔, 下里あゆ子他：右下腹部痛 で発症し，腸管壊死，穿孔，腹腔内出血を繰り返 して死亡した劇症型アメーバ症の 1 例。逓信医 $2012 ; 64: 213-221$

16）安倍正史, 国村利明, 尾松睦子他：再検査にて病 巣が確認された重度腸アメーバ症の 1 例. Clin Parasitol $2013 ; 24: 18-22$

17）増田 亨, 濱口哲也, 川村幹雄他：虫垂炎に合併 したアメーバ性肝膿瘍の 1 例. 治療 2014；96： $1404-1407$

18）中村雅憲, 青松直撥, 長谷川毅他：虫垂炎にて発 症したアメーバ性大腸炎の 1 例. 日外科系連会誌 2014 ; $39: 954-958$ 
19）森 大輔, 明石道昭, 姉川 剛他：虫垂炎症状に て発症した劇症型アメーバ性腸炎の 1 剖検例。診 断病理 $2015 ; 32: 88-92$

20）竹ノ谷隆, 平田 泰, 小林 隆他：急性虫垂炎の 術後に腹壁壊死と腸管穿孔をきたした赤痢アメー バ感染の 1 例. 日臨外会誌 $2015 ; 76: 797-802$

21) Ichikawa H, Imai J, Mizukami H, et al : Amoebiasis presenting as acute appendicitis. Tokai J
Clin Med 2016; $41: 227-229$

22）出井秀幸, 青葉太郎, 加藤岳人他：虫垂腫瘍を疑 い結腸右半切除後にアメーバ性虫垂炎と診断した

1 例. 日腹部救急医会誌 $2017 ; 37: 53-56$

23）阪本達也, 田端正巳, 藤村 侑他：虫垂炎および 肝膿瘍を発症した赤痢アメーバ症の 1 例. 日外感 染症会誌 $2018 ； 15: 678-682$

\title{
A CASE OF AMEBIC APPENDICITIS WITH ABDOMINAL WALL NECROSIS, INTESTINAL PERFORATION, AND INFECTIOUS MYOCARDITIS AFTER SURGERY
}

\author{
Yuji SUGIYAMA ${ }^{122)}$, Yoshiaki OSAKA ${ }^{1)}$, Fumiaki KATO ${ }^{1}$, Hideaki KAWAKITA ${ }^{1)}$, \\ Toru SAKURAI ${ }^{1)}$ and Akihiko TSUCHIDA ${ }^{2)}$ \\ Department of Surgery, Kohsei Chuo General Hospital ${ }^{1)}$ \\ Department of Gastrointestinal and Pediatric Surgery, Tokyo Medical University ${ }^{2)}$
}

A 48-year-old woman visited a doctor with a chief complaint of fever and abdominal pain. She was diagnosed with acute appendicitis and referred to our hospital. Since the symptoms improved with conservative treatment but became worse again after the start of a meal, she underwent emergency surgery. A necrotic appendix that had disintegrated near the root with abscess formation was found. The ileum ruptured into the abscess cavity. Partial cecal resection, partial small bowel resection, and abscess drainage were performed. Extremely poor postoperative infection control resulted in abdominal wall necrosis, cecal perforation, and acute heart failure due to infectious myocarditis. Therefore, the patient was managed in the CCU. Since Entamoeba histolytica was detected in the drainage on postoperative day 20, metronidazole treatment was started. Since the inflammatory reaction improved rapidly with adequate infection control, the patient was discharged on postoperative day 99. Despite the difficult postoperative management of acute appendicitis, anti-amoebic therapy effectively saved the patient's life after the diagnosis of entamoebiasis. This case is reported in the context of the literature.

Key words : acute appendicitis, amebiasis, sexually transmitted disease 